\title{
Potret Diri Digital dalam Seni dan Budaya Visual
}

\section{JOURNAL} OF URBAN SOCIETY'S ARTS

Volume 2 Nomor 2, Oktober 2015: 111-122

\section{Kusrini}

Jurusan Fotografi, Fakultas Seni Media Rekam, Institut Seni Indonesia Yogyakarta E-mail: kusrini.campus@gmail.com; HP: 085602122742

\begin{abstract}
ABSTRAK
Selfie merupakan bentuk tidak resmi (slang) dari potret diri digital (digital selfportraits). Keberadaannya semakin berkembang. National \#Selfie Gallery di London pada 2013 menunjukkan bahwa jenis foto ini memiliki kelayakan untuk masuk galeri dan disebut sebagai karya seni. Sejumlah 19 seniman berfoto selfee dan hasilnya dipamerkan dalam bentuk video berdurasi singkat, masing-masing sekitar 30 detik. Untuk sampai di ruang pamer galeri, foto-foto selfie tersebut melalui tahap kurasi oleh kurator. Terdapat seleksi teknik dengan perangkat yang ada di dunia seni. Pada tahap selanjutnya, foto-foto selfie tersebut masuk galeri. Saat lolos seleksi dan dipamerkan di ruang galeri, serta dinikmati audiens seni, digital self-portraits menjadi sebuah karya seni dengan nilai isi makna seni, termasuk nilai estetis, serta nominal tertentu saat dibeli oleh kolektor. Jenis foto yang mengelilingi masyarakat kota tidak hanya selfie dan potret diri, namun semakin beragam. Di mana pun bertemu dengan foto, hingga dalam pengambilan keputusan maupun tindakan, berdasarkan pada apa yang dilihat. Di ranah ini, foto sudah menjadi bagian dari budaya masyarakat membentuk budaya visual. Dari budaya visual ini, bidangbidang kehidupan lain ikut terpengaruh. Ketika foto menjadi bagian tidak terpisahkan dari kehidupan ataupun cara hidup masyarakat, bidang lain seperti ekonomi dan sosial turut larut di dalamnya. Perekonomian menjadikan dunia visual sebagai lahan bisnis yang menjanjikan. Dari sisi sosial, masyarakat menggantikan interaksi dan komunikasi langsung dengan media digital. Melihat dan mengukur seseorang dari relasi dari di media sosial, dan menilainya dari visual yang tertampil di jejaring sosial tersebut.
\end{abstract}

Kata kunci: digital self-portraits, seni, budaya, visual

\begin{abstract}
Digital Self-Portrait in Art and Visual Culture. Selfie is a slang form of digital self-portrait. Now, its development has been increasing. National \#Selfie Gallery in London in 2013 showed the eligibility of this type to enter the gallery and called it as a work of art. There were 19 artists taking their selfie and displayed the works in the form of short videos, each was about 30 seconds. Being displayed in the gallery, these photos of selfie had been through stages of curation by curators before they were displayed in the gallery. There was a technique of selection with the existing devices in the art world. When photographs passed the selection and were exhibited in the gallery space, and were enjoyed by the audiences, the digital self-portraits become a work of art which contain the art values in content, including aesthetics, and certain nominal when purchased by collectors. The types of photo surrounding the urban community are not only selfie and self-portrait, but more various upon them. Wherever photos are found, and when taking the decision and action in society, they are much influenced on what are seen. Based upon this realm, they have already become a part of community art which forms the visual culture. From this visual culture, other areas of life are affected. When photos become the inseparable part of life or community way of life, other areas like economic
\end{abstract}


and social are fused within them. The economics makes the visual area becoming the prospective business area. From the social side, the community replaces the interaction and direct communication with the digital media. By having this understanding, we are able to see and measure a person by looking at his/her social relation through the social media, and giving the showed value as being found in its social networking.

Keywords: digital self-portrait, art, culture, visual

\section{Pendahuluan}

"Nunggu guru selfie dulu, ganteng dikit cekret, ganteng banyak cekrek, ganteng banget cekrek cekrek cekrek, upload....". Kata-kata tersebut terdapat di salah satu iklan operator seluler dalam program "Iritology", yaitu promosi untuk layanan seluler ngobrol irit, internet irit, dan awet irit (http://www. antaranews.com/). Iklan bertema selfie ini tayang di beberapa stasiun televisi swasta di Indonesia. Kata-kata yang lucu serta tingkah yang menarik, membuat iklan ini mudah diingat, serta menjadi salah satu fenomena yang banyak menarik perhatian publik media sosial. Video iklan ini pun banyak

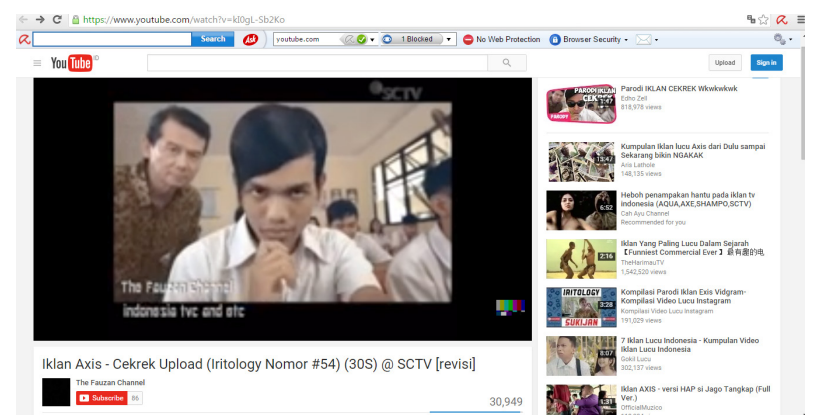

Gambar 1. Capture iklan Axis. (Sumber: https://www. youtube.com/watch?v=klogL-Sb2Ko)
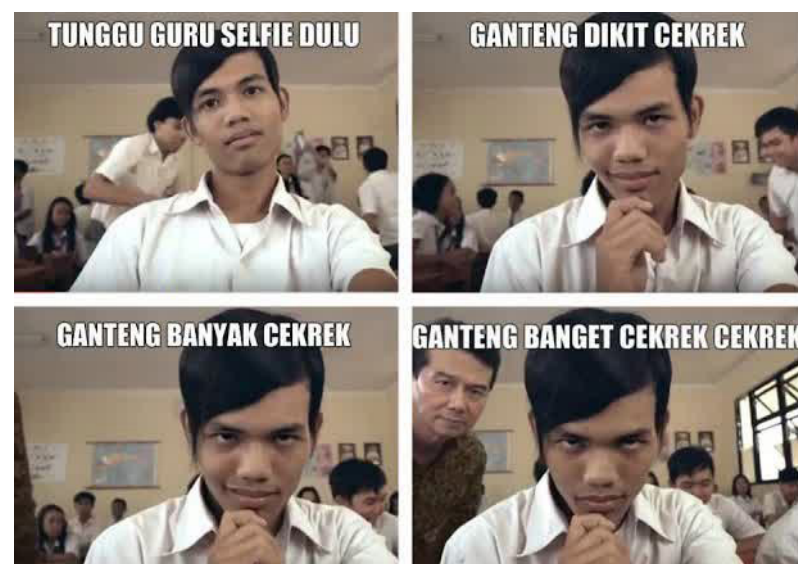

Gambar 2. Capture iklan Axis Iritology. (Sumber: http:// www.kalongkurus.com/) diunduh di blog-blog ataupun website, bahkan banyak memunculkan parodi yang berkaitan dengan iklan ini. Hal ini terlihat seperti di youtube. com yang telah dilihat sebanyak 30.949 kali. Di sisi lainnya, parodi iklan "cekrek" ini telah dilihat sebanyak 820.261 pada waktu yang sama. Iklan ini menjadikan selfie kembali menjadi perhatian.

Selain itu, banyaknya peristiwa tragis karena kecerobohan saat selfie menjadikan jenis pemotretan ini masih menjadi perhatian masyarakat. Seperti terjadi di Gunung Merapi Yogyakarta, serta di Pantai Bajulmati Malang Selatan. Di Yogyakarta, pada Mei 2015, seorang mahasiswa terjatuh ke kawah Gunung Merapi setelah selfie di bebatuan yang terdapat di bibir kawah. Pada bulan yang sama, di Malang, seorang warga Desa Banjarsari, Kecamatan Jetis, Kabupaten Mojokerto, tergulung ombak saat selfie dengan latar belakang Pantai Bajulmati. Saat selfie kedua, tiba-tiba ombak datang dan korban tidak dapat menyelamatkan diri (http://www2.jawapos.com/). Selfie berujung maut di Pantai Bajulmati, Malang, kembali terjadi. Lima orang wisatawan diketahui sedang selfie saat ombak datang dan menggulung para wisatawan.

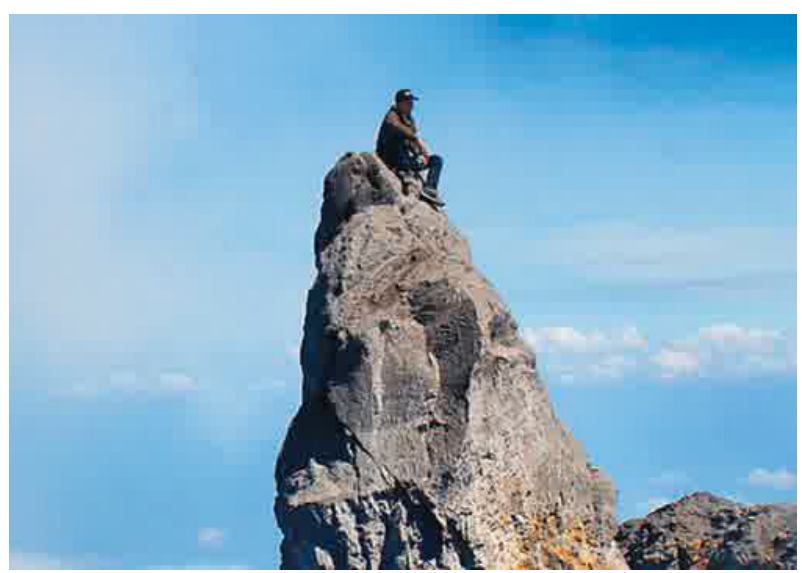

Gambar 3. Foto terakhir "korban" selfie saat di atas batu di bibir kawah Gunung Merapi, yang diunggah di media sosial. (Sumber: http://www2.jawapos.com/) 
Satu orang berhasil diselamatkan, satu ditemukan dalam keadaan meninggal, dan tiga orang masih hilang (http://surabaya.tribunnews.com/).

Di luar negeri terdapat juga beberapa peristiwa buruk yang berkaitan dengan selfie. Pada Juni 2015, seseorang berumur 21 tewas terjadi di Jembatan Moskow setelah selfie di sana, sedangkan di Texas, Amerika Serikat, Rabu, 2 September 2015, seorang ayah tewas setelah selfie dengan cara menodongkan pistol ke lehernya sendiri. Di Taman Nasional Yellowstone, Amerika Serikat, lima orang tewas karena selfie yang terlalu dekat dengan bison. Berkait dengan berbagai peristiwa tersebut, muncul kampanye tentang selfee seperti kampanye antirokok atau anti-narkoba, "Selfie Dapat Mengambil Nyawamu” (http://www.cnnindonesia.com/).

Peristiwa lain terjadi di Romania. Seorang gadis tewas tersengat listrik ketika nekad naik ke atap kereta api untuk mengambil selfie. Anna Ursu, nama gadis 18 tahun, ini sebelumnya dikenal sangat kecanduan selfie. Bersama seorang kawannya ke stasiun kereta api di timur laut Romania untuk membuat selfie spesial dan mengunggahnya ke Facebook. Mereka naik ke atas sebuah gerbong kereta yang sedang "parkir". Namun tidak sengaja, kaki kanannya menyentuh kabel listrik yang melintang. Akibatnya, tubuh gadis itu tersengat listrik bertegangan 27.000 volt, yang langsung membakar tubuh Anna, sedangkan temannya selamat karena terpental (http://internasional.kompas.com/).

Peristiwa buruk sebenarnya telah banyak terjadi akibat kecerobohan saat selfie, namun hal itu tidak membuat masyarakat menjadi jera. Selfie, berfoto diri untuk diunggah ke media sosial masih banyak dilakukan dalam berbagai suasana dan

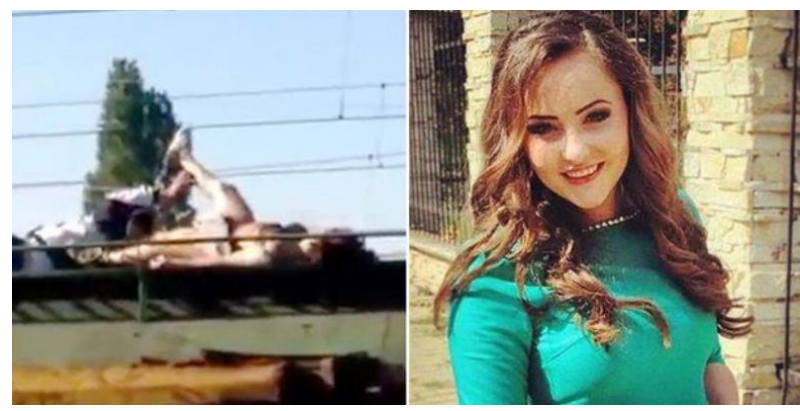

Gambar 4. Kiri, tubuh Anna Ursu (18) tergeletak di atap gerbong kereta api setelah tersengat listrik bertegangan tinggi. Foto kanan adalah Anna Ursu semasa hidup.

(Sumber: http://internasional.kompas.com/) tempat. Fungsi selfie pun mulai beragam, lebih dari sekadar unjuk diri sendiri, namun sudah merambah ke unjuk diri sebagai bagian dari kelompok sosial atau masyarakat tertentu. Di tengah masyarakat urban (perkotaan), selfie mengarah ke pembentukan citra diri yang diinginkan. Segala sesuatu diukur dari apa yang dilihat dan dihitung, bukan dari apa yang dirasakan. Citra diri dapat dikonstruksi melalui foto-foto yang diunggah ke media sosial karena citraan ini dibentuk oleh potongan-potongan realitas yang sudah "diseleksi" untuk ditampilkan kepada audiens media sosial (Kusrini, 2013:46).

\section{Foto dalam Masyarakat Urban}

Urban atau kota adalah sebuah tempat, ruang, dan teritorial, yang di dalamnya berlangsung pergerakan manusia dan barang; interaksi manusia dengan manusia secara sosial dalam berbagai skalanya; komunikasi di antara manusia dalam berbagai medianya; segmentasi manusia di dalam berbagai bentuk segmentasi sosial dan politik segmentasi: sosial, politik, ekonomi, kultural (Piliang, 2010:229). Pengertian lain tentang kota sebagai kota digital adalah sebuah tempat yang di dalamnya berlangsung aktivitas ekonomi, sosial, politik dan kultural; yang di dalamnya terbentuk berbagai relasi antar-manusia; dan yang di dalamnya dibangun berbagai realitas sosial di dalam sebuah ruang-waktu yang nyata.

Hubungan antarmanusia di dalam kota konvensional berlangsung secara tatap muka. Seiring perkembangan abad informasi, digital, dan cyberspace dewasa ini telah mengubah potret kota, yaitu relasi dan komunikasi berlangsung lewat mediasi teknologi digital. Tempat dan ruang kota digantikan oleh tempat elektronis (telepon, short message service, televisi) atau ruang virtual (internet), yang di dalamnya berlangsung relasi virtual (Piliang, 2010:231). Ruang seni dan budaya masyarakat kota pun mengalami perubahan seiring perkembangan teknologi dan media informasi. Teknologi menjadi bagian dari relasi dan interaksi, komunikasi dengan media visual semakin kuat menelisik masuk ke dalam budaya masyarakat kota.

Selfie menjadi bagian dari media komunikasi interaksi masyarakat kota. Saat bertemu antarorang, 
orang-orang tersebut tetap memegang telepon genggam (handphone). Saling potret atau potret diri bersama, kemudian diunggah ke media sosial. Masing-masing saling berkomentar melalui media sosial, padahal duduk berdampingan. Alat digital menggantikan komunikasi antarpersonal. Fotofoto di media sosialnya dianggap lebih menarik dan menjangkau lebih banyak orang dalam interaksi sosial. Ruang-ruang yang telah terisi oleh media visual dan digital semakin banyak. Bahkan selfie mulai "masuk" galeri dan dapat disebut sebagai karya seni.

Dalam perspektif budaya, bergantinya ruang interaksi tersebut membawa beberapa dampak di masyarakat. Perkembangan teknologi yang sangat cepat diikuti oleh cepatnya perubahan budaya di masyarakat. Kondisi ini sangat ditunjang dengan kemudahan-kemudahan yang ditawarkan oleh berbagai aplikasi teknologi. Hal ini membuat perilaku orang-orang berubah. Arah budaya juga mengalami perubahan, menuju budaya visual, di mana segala sesuatu berbasis visual. Segala sesuatu yang diputuskan atau dilakukan, semua dipengaruhi oleh hal-hal yang terlihat atau visual. Budaya visual adalah cara hidup sehari-hari di mana pemahaman dan proses pengambilan keputusan dipengaruhi oleh hal-hal yang visual. Contoh sederhana, saat membeli shampo di supermarket. Pilihan lebih sering ditentukan oleh tampilan visual dari sampo tersebut (kemasan) daripada keterangan yang tertulis di botolnya (http://sejarahfoto.com/).

\section{“Pengakuan” untuk Selfie, sebagai Seni}

Saat istilah selfie ditetapkan sebagai salah satu kata dalam kamus bahasa Inggris atau Oxford English Dictionary's Word of The Year 2013 pada November 2013 (http://www.oxforddictionaries. $\mathrm{com} /$ ), selfie hanya mengarah ke perilaku atau tindakan memotret diri sendiri, melalui telepon pintar atau kamera pada alat telekomunikasi, kemudian mengunggahnya ke media sosial. Dalam batas definisi ini, selfie lebih pada dokumentasi diri sendiri oleh diri sendiri. Untuk sampai di tataran seni, sebuah karya perlu semacam "pengakuan" atau "persetujuan" dari pihak-pihak tertentu yang terlibat dalam dunia seni, begitu juga dengan selfie.
Foto hasil selfie mulai mendapat perhatian di dunia seni. Pada masa sekarang ini selfie dilihat dari sisi pembuat ataupun karya foto yang dihasilkan. Selfie bahkan mulai dianggap sebagai bagian dari sebuah seni. "Pengakuan" tersebut terdapat di ajang pameran visual "Moving Image Contemporary Art Fair" di The Bargehouse, London. Pameran yang diikuti seniman dari Eropa dan Amerika Serikat ini berlangsung pada 17-20 Oktober 2013.

Salah satu instalasi video yang ditampilkan adalah "The National \#Selfie Gallery”. Foto-foto selfie dibentuk dalam video pendek. Terdapat 19 seniman yang terlibat dengan masing-masing tampilan kurang lebih 30 detik dalam bentuk potongan gambar (trailer) seperti film. Fotofoto itu mengalami proses seperti karya seni lain sebelum masuk galeri, yaitu melalui tahap seleksi atau kurasi. Diseleksi, khususnya untuk praktik publikasi karya foto itu sendiri, dari puitis konvensional hingga komentar lucu pada tampilan dan eksperimental media baru dari foto potret (http://www.theatlantic.com/).

Isi dari video tersebut pada dasarnya adalah foto-foto selfie, foto yang dibuat diri sendiri dan diunggah ke media sosial meskipun semuanya ditayangkan dalam bentuk video. Saat foto selfie ditampilkan di galeri seni, baik secara langsung maupun tidak, terdapat "pengakuan" bahwa foto selfie merupakan bagian dari karya seni. Foto-foto tersebut apabila juga melalui tahap kurasi seperti karya seni yang lain, semakin menguatkan posisinya sebagai bagian dari dunia seni kontemporer. Salah seorang kurator Moving Image Contemporary Art

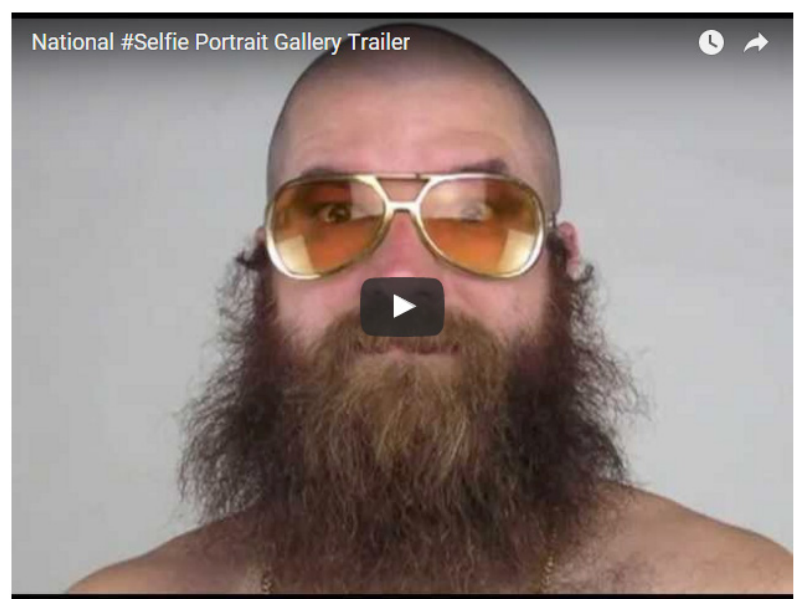

Gambar 5. Capture dari video trailer "The National \#Selfie Gallery". (Sumber: http://www.time.com/) 
Fair di London, Kyle Chayka, kepada Time online (http://time.com/) menyebut bahwa selfie harus dilihat dengan lebih kritis. Selfie berangkat dari potret diri dalam format yang diimprovisasi dan cepat.

Kurator yang lain yaitu Marina Galperina kepada media yang sama dalam wawancara Lightbox, membenarkan jika selfie berasal dari foto potret dengan keadaan objek yang semakin sadar diri akan kamera. Pada sisi yang lainnya, kemajuan teknologi membuat foto potret semakin demokratis sehingga setiap orang dapat berfoto dengan lebih bebas. Selfie merupakan sebuah media yang sangat umum dari komunikasi dan komunikasi visual terutama bagi orang-orang yang menghabiskan banyak waktu bekerja secara digital dan hidup dalam media online.

Artikel National \#Selfie Portrait Gallery dari Moving Image memaparkan bahwa selfie adalah bentuk tidak resmi (slang) dari potret diri digital (digital self-portraits) yang ditemukan di semua jejaring sosial. Potret diri disebutkan juga sebagai medium kreatif yang paling demokratis untuk menampilkan diri sebagai bagian dari masyarakat dan sebuah alat katarsis-teknik menyalurkan emosi yang terpendam baik untuk seniman (artis) maupun bukan seniman dengan maksud yang sama. National \#Selfie Portrait Gallery mengeksplorasi penampilan, kepribadian/personalitas, keaslian, dan ekspresi yang ada pada bentuk \#selfie, dari kepuasan instant pada kreasi hingga kontes popularitas dalam publikasi (http://www.moving-image.info/).

Berdasar sisi konsep, seni memiliki banyak pengertian. Seorang sastrawan Rusia, Leo Tolstoy (Bahari, 2008:73) menyatakan bahwa aktivitas

\begin{tabular}{ll}
\hline \multicolumn{1}{c}{ United States } & \multicolumn{1}{c}{ Europe } \\
\hline Anthony Antonellis & Kim Asendorf \& Ole Fach \\
Jennifer Catron \& Paul Outlaw & Jesse Darling \\
Jennifer Chan & Leslie Kuless \\
Yung Jake & Carlos Sáez \\
Rollin Leonard & Daniel Swan \\
Angela Washko & Addie Wagenknecht \\
Jayson Musson & Saoirse Wall \\
Petra Cortright & \\
Bunny Roggers & \\
Alexander Porter & \\
\hline
\end{tabular}

Tabel. Nama seniman peserta National \#Selfie Portrait Gallery. (Sumber: http://www.moving-image.info/) seni ialah untuk membangkitkan perasaan dengan suatu yang pernah dialami baik melalui perantaraan gerak, garis, warna, suara, maupun kata. Oleh karena itu untuk dapat dilihat sebagai sebuah seni, sebuah karya harus memenuhi tiga sarat dipandang dari sisi seniman dan karya yang tercipta (Tolstoy (1960:139).

Syarat pertama, nilai ekspresi tergantung pada besar-kecilnya kepribadian sang seniman. Tolstoy mempergunakan "individualitas" seniman. Semakin menonjol individualitas, maka akan semakin kuat daya pengaruh pada penerimanya. Individualitas ini menekankan bobot sikap jiwanya. Syarat kedua, nilai ekspresi tergantung besar-kecilnya kejelasan, kejernihan perasaan yang diungkapkan. Seniman mendasarkan diri pada nilai universal manusia. Syarat ketiga, nilai seni bergantung pada besar-kecilnya kejujuran seniman. Perasaan yang mencapai tingkat universal akan dipahami orang banyak. Kejujuran ini muncul dari lubuk hati terdalam, yang mendesak untuk diungkapkan kepada orang lain. Ekspresi kejujuran ini memerlukan penguasaan teknik seni yang secerdas mungkin. Kejujuran dalam seni berkaitan juga dengan keaslian karya dari seniman tersebut. Karya seni yang asli tetap memiliki nilai tinggi meskipun seniman sudah tiada. Kejujuran dan keaslian karya yang merupakan bagian dari karakter seniman akan menunjukkan bagaimana seniman ini berkarya yaitu seberapa jujur dikatakan sebagai seniman.

Ekspresi seniman dalam hal ini sekaligus objek foto, tidak sekadar ekspresi wajah, tetapi juga termasuk perasaan yang terungkap pada perilaku yang tertangkap kamera, serta kecerdasan teknik yang dapat menjadikan hal pribadi menjadi nilai universal manusia. Nilai universal manusia dalam seni ini dalam pandangan Schirato \& Jen Webb (2004:107) disebut sebagai high art atau "seni tinggi” yang di dalamnya terdapat kondisi sosial dan ideologi, di mana kerja seni tersebut kemudian dapat dibuat dan disebarkan. Seni sementara itu menyediakan teknik ungkap, struktur dan mekanisme untuk memproduksi pernyataan artistik individu. Seni dalam pengertian yang lainnya menyediakan perangkat untuk berekspresi secara individual, sedangkan budaya menyediakan 
nilai-nilai sosial dan ideologi untuk melengkapi karya tersebut secara substansi sehingga dapat dinikmati orang lain juga.

Foto-foto selfie yang dipamerkan dalam National \#Selfie Portrait Gallery berbentuk video berdurasi pendek. Inti dari isi video tersebut meskipun berdurasi pendek adalah foto selfie dari seniman-seniman. Contoh karya tersebut di antaranya terpapar dalam gambar 6-11. Berdasar totalitas jumlah seniman yaitu 19 seniman maka terdapat 17 selfie seorang diri dan dua foto lainya adalah selfie dua seniman. Foto-foto tersebut dipilih enam berdasarkan tampilan imaji yang sesuai dengan arah tulisan ini serta dianggap dapat mewakili foto-foto lain. Secara umum, hampir semua wajah seniman terlihat dalam foto. Dalam karya tersebut hanya terdapat satu selfie yang tidak terdapat wajah seniman yaitu karya Daniel Swan, seniman sekaligus arsitek yang membuat video seni abstrak. Foto ini menampilkan gambar tangan yang sedang memegang telepon genggam dengan benang warna merah muda yang menjuntai ke belakang telepon.

Ekspresi individu yang terungkap melalui imaji yang terjadi dapat dilihat langsung dalam semua gambar 6-11, meskipun dengan teknik ungkap berbeda. Dalam selfie Alexander Porter, Carlos Sáez dan Anthony Antonellis terdapat

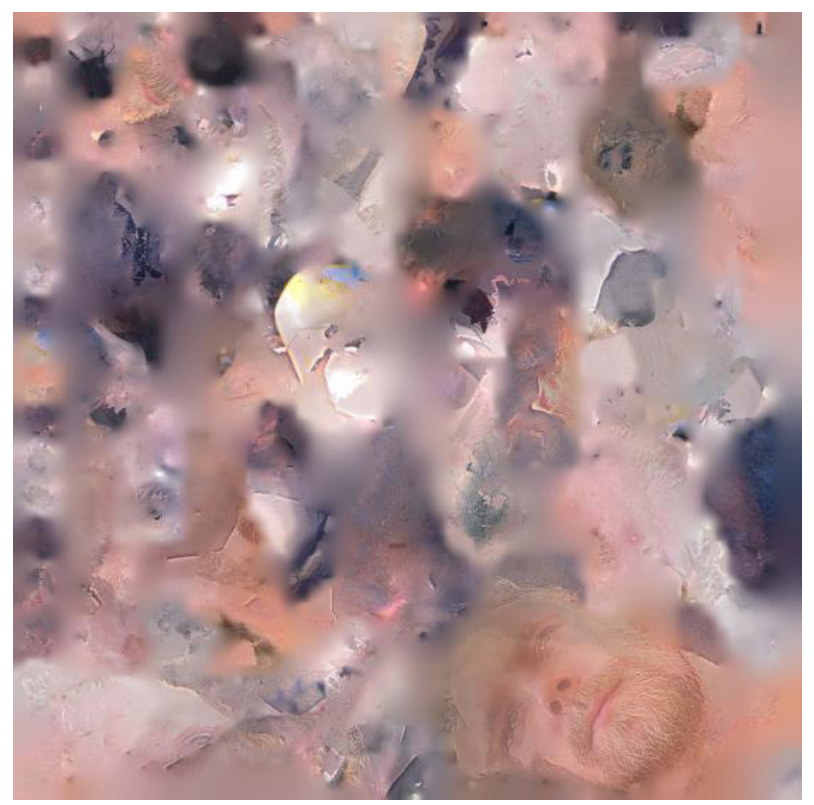

Gambar 6. Selfie Alexander Porter, fotografer yang bekerja dengan inframerah melalui perangkat komputer. (Sumber: http://time.com/) teknik ungkap yang cerdas serta pemikiran tajam (Tim Penyusun, 2008:279) dalam menggunakan teknik tertentu dari fotografi. Dalam pemaknaan yang berbeda maka selfie Jennifer Catron dan Paul Outlaw lebih mengarah pada cara yang menarik dan unik. Karya selfie tersebut apabila dikaitkan dengan latar belakang minat seni Jennifer Catron dan Paul Outlaw maka dapat diasumsikan bahwa selfie tersebut mengandung sindiran atau satire. Di sisi lain, cara yang indah digunakan oleh Petra Cortright. Petra Cortright tampil cantik dan menunjukkan sisi kecantikan wajahnya dengan sudut pengambilan gambar dari sisi kiri dan rambut digerai ke bahu kanan. Sudut bibir agak naik ke atas menarik seulas senyum tipis untuk menambah keindahan ekspresi. Hal lain yang menarik, kepribadian/personalitas seniman yang terseleksi, tercatat memiliki prestasi di bidangnya khususnya yang berkaitan dengan seni ataupun media digital.

Penampilan agak berbeda terlihat dari selfie Leslie Kulesh yaitu pada saat memotret diri di dalam toilet atau berlatar belakang tempat pembuangan

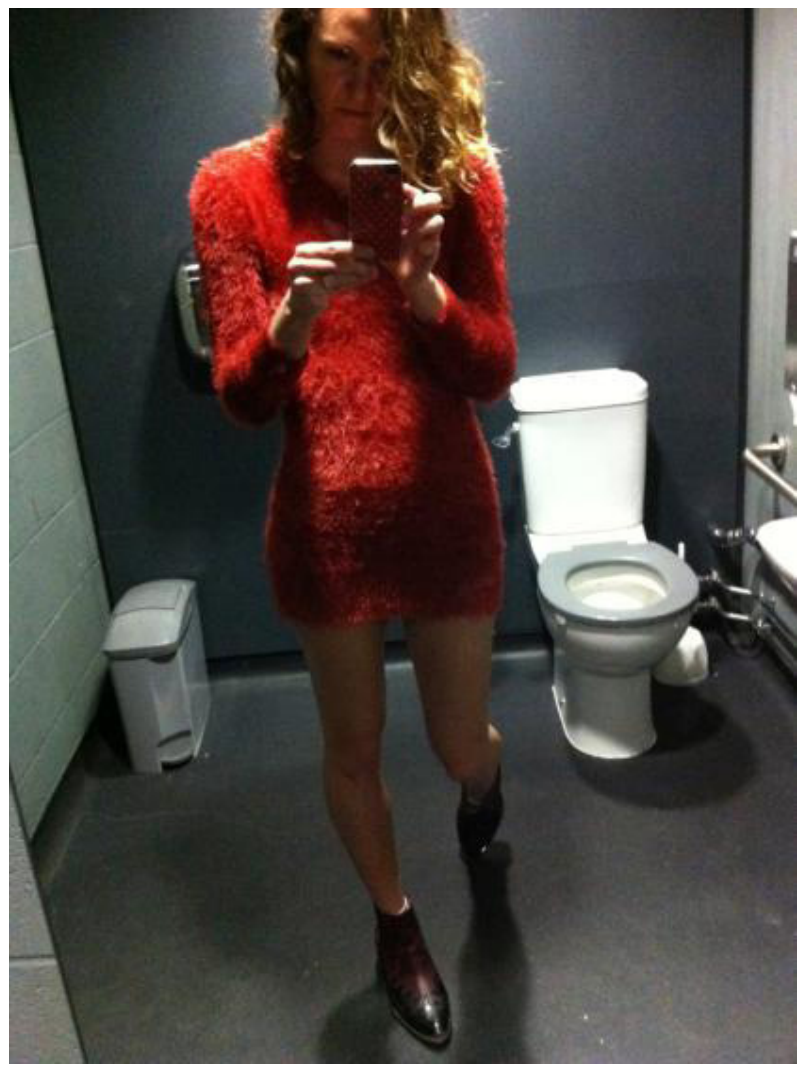

Gambar 7. Selfie Leslie Kulesh, seniman dengan karya pertunjukan, video, dan patung tentang identitas politik. (Sumber: http://time.com/) 
kotoran tubuh. Selfie biasanya secara umum lebih untuk menunjukkan sesuatu yang bagus. Selfie apabila sudah masuk ranah seni maka tidak selalu berkaitan dengan sesuatu yang bagus atau indah secara penampilan. Masuknya benda yang tidak biasa ke dalam sebuah karya seni, pernah terjadi saat tempat untuk membuang air kecil, urinoir, didaftarkan oleh Marcel Duchamp pada 1917 di Society of Independent Artists. Benda porselen tersebut diberi judul Fountain dan terbukti menjadi hasil kerja seni yang paling berpengaruh terhadap seni di abad ke-20 (http://www.theartstory.org/). Seni merupakan sesuatu dari dalam diri manusia yang diekspresikan keluar melalui cara-cara yang tersedia di dunia seni. Digital self-portraits atau foto selfie telah membuktikan hal tersebut melalui fotofoto yang tertampil sebagai new media art video.

Ekspresi teknik terlihat lekat dalam imaji selfie National \#Selfie Portrait Gallery. Foto 6-11 menggunakan teknik fotografi secara umum. Selfportrait itu sendiri dilakukan oleh para seniman dengan memanfaatkan bantuan cermin atau dengan cara biasa yaitu tangan yang terjulur ke depan. Szarkowski (Bugin, 2010:262) menetapkan

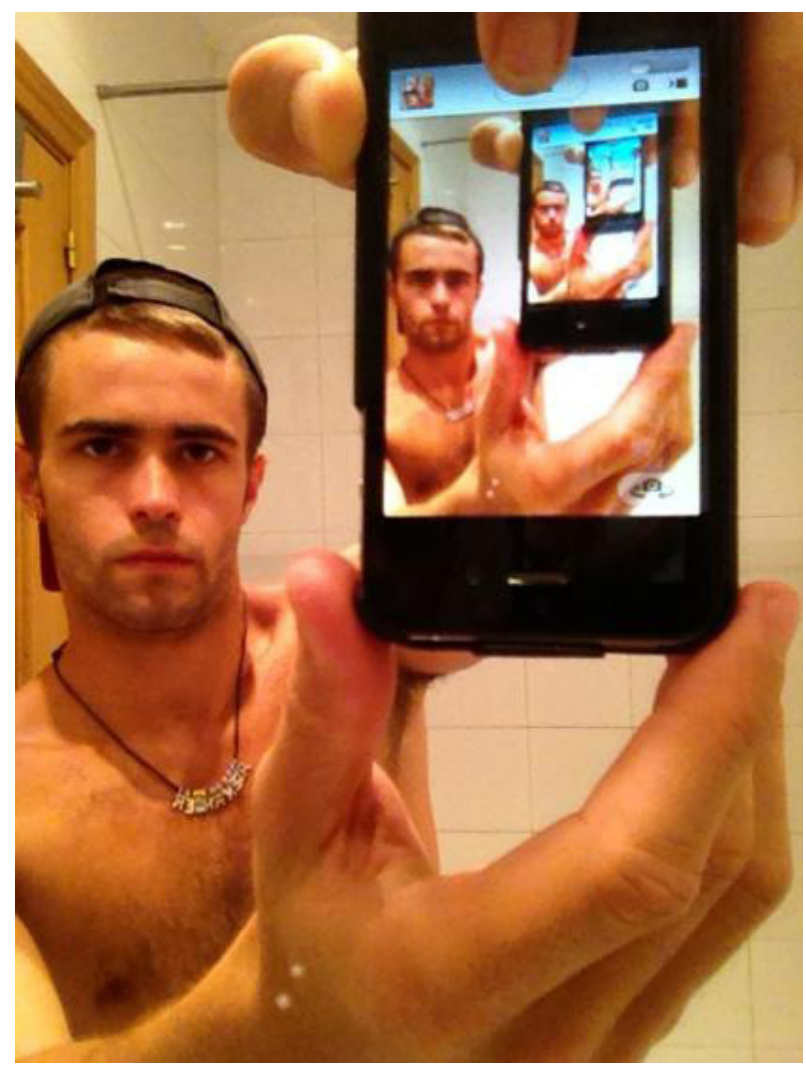

Gambar 8. Selfie Carlos Sáez, seniman dengan kemampuan digital imaging. (Sumber: http://time.com/) kategori bagi norma pokok fotografi agar bidang ini dapat beroperasi dan bekerja dalam bidang seninya yang unik dalam hakikat medianya. Kategori itu diidentifikasikan sebagai 'benda itu sendiri' (the thing itself), 'rincian' (the detail), 'bingkai' (the frame), 'waktu' (time), dan 'tempat yang menguntungkan' (vantage point).

Melalui identifikasi kategori tersebut, sebuah foto harus kembali ke dasar dan memiliki ceritanya sendiri. National \#Selfie Portrait Gallery semuanya merupakan gambar yang diambil dengan kamera yang bekerja dengan cahaya. Berdasar etimologis fotografi (photo-graphy) yang menggambar dengan cahaya maka the thing itself memberikan asal usul benda yang sudah sesuai norma pokoknya. Rincian dapat dilihat melalui teknik yang digunakan. Teknik yang terdapat dalam foto 6-11 adalah sudut pengambilan gambar, sumber cahaya, dan cara penyajian yang meliputi pembingkaian foto. Cara pengambilan gambar ala selfie adalah tangan yang terjulur dan sudut gambar melebihi lengan, objek tahu jika objek itu memotret dirinya sendiri dan audiensnya juga tahu siapa yang dipotret dan oleh siapa. Semua hal itu dianggap menjadi ciri khas selfie yang menarik (http://time.com/).

Berdasar sudut pencahayaan, foto 6-11 menggunakan cahaya yang cukup dari sekitarnya. Pencahayaan yang cukup dari sekitarnya

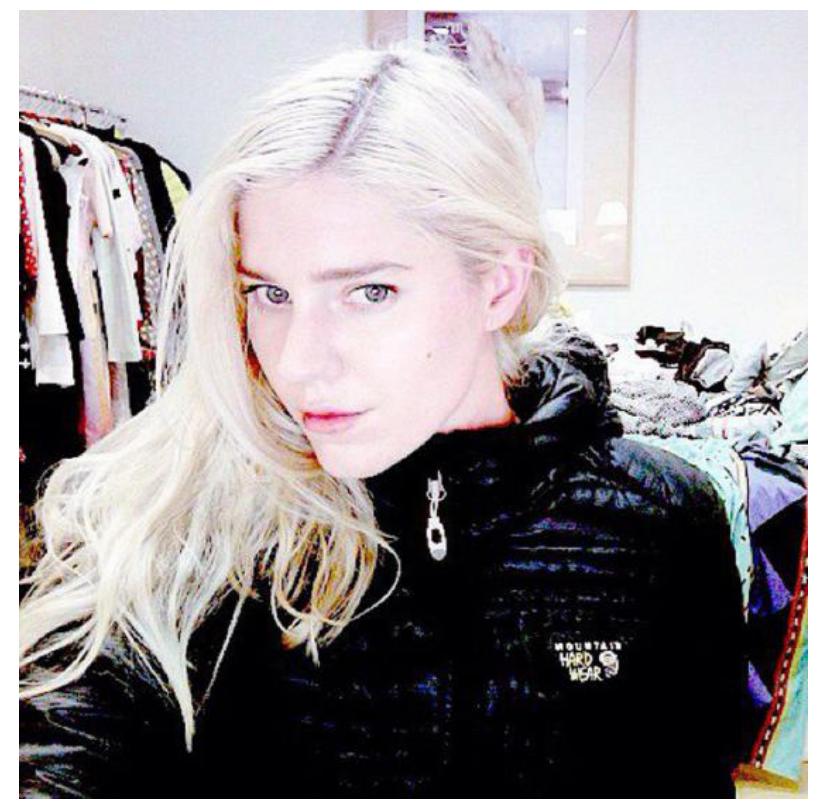

Gambar 9. Petra Cortright, seniman yang menjual lukisan digital, menerbitkan buku Hell Tree at Badlands. (Sumber: http://time.com/) 
menjadikan tidak hanya kamera-terlihat dari tidak adanya pantulan cahaya yang membuat fotofoto tersebut terlihat jelas dalam detil objek foto. Terdapat salah satu pencahayaan yang menarik yaitu gambar 7 dengan menggunakan pencahayaan atas belakang sehingga memunculkan efek seperti rim light atau garis tepi warna putih pada bagian atas subjek. Dalam pembingkaian dapat dilihat bagaimana selfie tersebut dalam bentuk aslinya sebelum dibuat video. Para seniman tersebut sebagaian besar mengetahui cara membuat foto mereka menjadi menarik.

Cara penyajian yang unik dan jelas menggunakan teknik komputer ataupun perangkat lunak terdapat dalam gambar 6, 8 dan 11. Gambar 6 menggunakan efek inframerah di mana efek lain sejajar dengan wajahnya. Gambar 8 dan 11 menggunakan cara tertentu secara teknik manual ataupun teknik perangkat lunak. Kategori 'waktu' (time) dan 'tempat yang menguntungkan' (vantage point) merujuk ke peristiwa yang tepat untuk menempatkan sebuah foto sebagai sebuah karya seni.

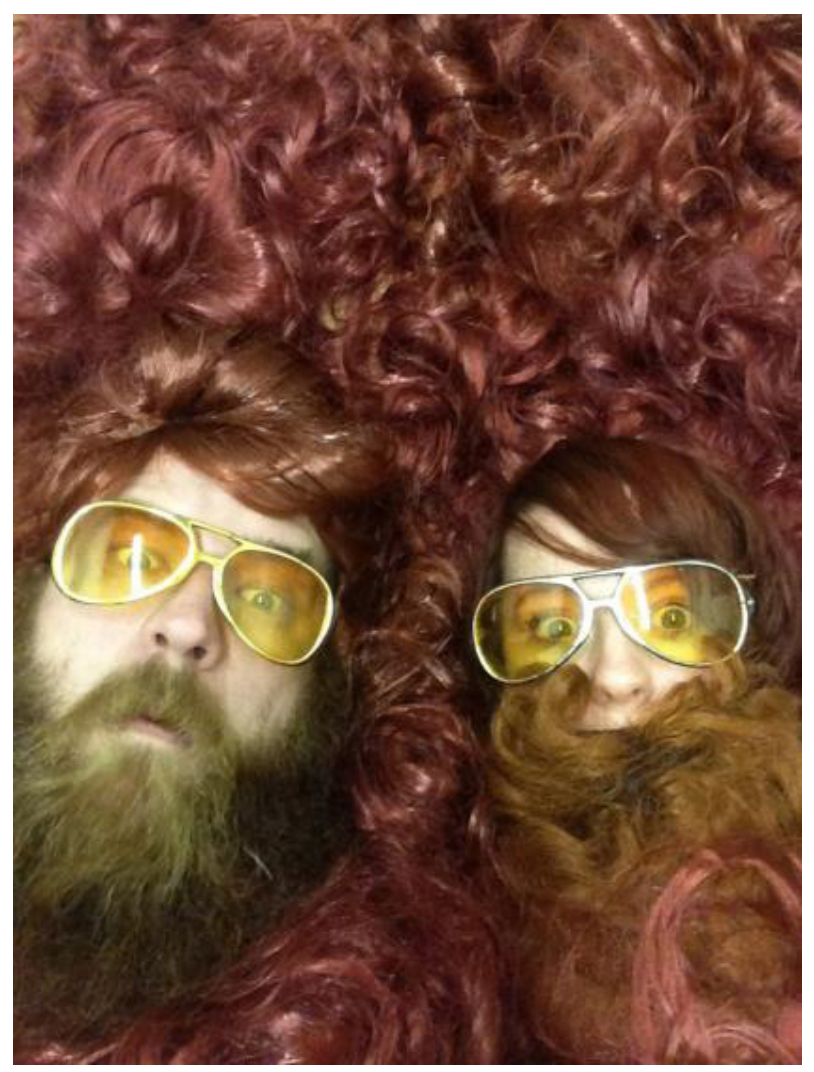

Gambar 10. Jennifer Catron and Paul Outlaw, berkolaborasi dalam kerja dan pertunjukan ritual penumbangan dan pengecaman (pemerintah).(Sumber: http://time.com/)
Pameran dan galeri menjadi bagian yang melekat dalam operasional digital self-portraits sebagai seni.

"Pengesahan" selfie sebagai seni sudah diungkapkan dengan jelas oleh kedua kurator Image Contemporary Art Fair di London yaitu Kyle Chayka dan Marina Galperina. Keduanya adalah seniman dan penulis lepas yang berbasis di Amerika Serikat. Mereka sependapat bahwa selfie sebenarnya sudah dari dulu ada dalam seni rupa. Selfie bahkan telah dilakukan oleh seniman dan hasilnya disebut sebagai seni (http://time. com/). Dalam National \#Selfie Portrait Gallery, para seniman melakukan seleksi terhadap foto selfie sebelum dipamerkan, termasuk cara penyajian yang dilakukan dengan video. Dalam tahap ini, sebuah karya sedang melalui tahap identifikasi yaitu dapat dimasukkan di galeri atau tidak. Sebuah "benda" yang kemudian disebut karya apabila telah lolos tahap seleksi dan terpajang di galeri maka sejak saat itulah dapat dikatakan sebagai benda atau karya seni atau karya dari kerja seni. Nilai-nilai yang terkandung dalam selfie tersebut juga semakin meningkat. Hal tersebut sangat berhubungan dengan nilai isi makna dan estetis maupun nilai nominal ketika dibeli oleh kolektor.

Schirato \& Webb (2004:110) menjelaskan bahwa sesuatu adalah seni jika seseorang atau sekelompok orang dengan kewenangan atau keahlian melakukan identifikasi sesuatu itu sebagai seni. Kewenangan dari "penjaga gawang" (gatekeepers) yang menawarkan seseorang tempatagen atau struktur dengan wilayah seni seperti

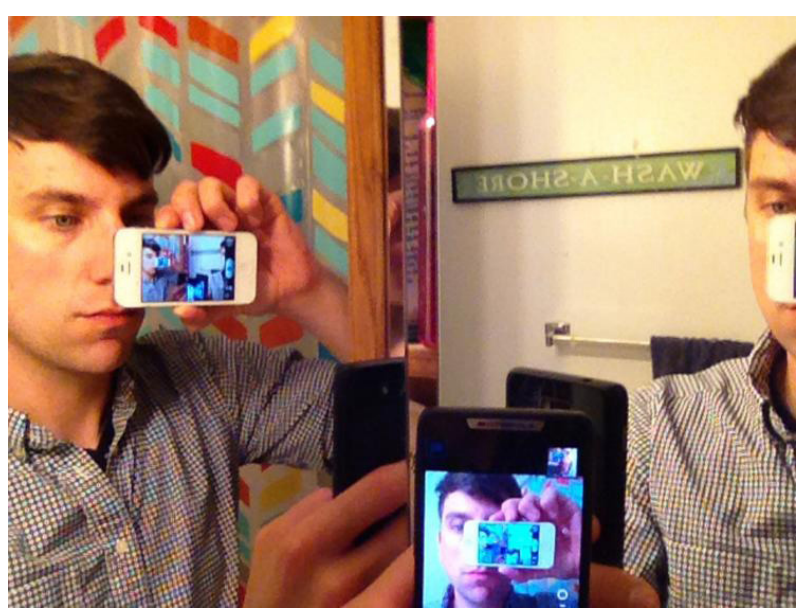

Gambar 11. Anthony Antonellis, seniman dengan praktik mikro-kuratorial. (Sumber: http://time.com/) 
galeri dan kurator, lembaga pembentuk seniman, penerbit, kritik serta penulis seni, perusahaan penyelenggara teater, penyelenggara seni maupun departemen seni milik pemerintah yang dapat membuat perbedaan antara segala sesuatu disebut sebagai sebuah gundukan batu atau piramida. Kedua kurator National \#Selfie Portrait Gallery dan Galeri The Bargehouse London memiliki kewenangan untuk memberikan pengabsahan atau pengakuan bahwa sebuah karya itu termasuk seni atau bukan seni. National \#Selfie Portrait Gallery merupakan peristiwa penting bagi perkembangan dunia fotografi khususnya foto potret.

Foto selfie meskipun melalui National \#Selfie Portrait Gallery menjadikannya dapat disebut sebagai seni, namun bukan berarti semua foto selfie kemudian secara acak dapat disebut sebagai seni. Terdapat begitu banyak kategori yang harus dilalui serta terdapat banyak sisi yang perlu dilihat. Persetujuan, baik secara tertulis maupun tidak tertulis yang disebut konvensi dapat menyatakan bahwa sesuatu itu adalah seni serta dapat melegitimasi suatu benda menjadi karya seni. Seleksi selfie dalam National \#Selfie Portrait Gallery juga dilakukan melalui kepuasan sesaat dari pemilik akun yang terlihat dari popularitas dalam publikasi. Hal ini berdasar atas banyaknya like atau respons yang diperoleh dalam setiap foto yang diunggah. Cara seleksi ini dapat menjadi bagian dari legitimasi atau persetujuan audiens tentang layak tidaknya selfie itu disebut sebagai karya seni. Sebuah benda bisa jadi saat ini tidak dapat disebut seni namun suatu saat bisa jadi disebut sebagai seni, karena seni selalu berubah dan berkembang seiring waktu. Begitu juga pada saat di mana benda itu dimunculkan di antara karya seni lain menjadi bagian yang penting agar sebuah benda atau kerja menjadi bagian dari dunia seni. Hal tersebut merupakan sebuah tempat yang tepat bagi "kemunculan" benda yang disebut karya seni misalnya di galeri, museum, atau komunitas seni.

\section{Fotografi dan Perubahan Budaya}

Budaya atau kebudayaan (culture) menjadi salah satu faktor yang mempengaruhi kehidupan manusia. Hal ini karena budaya tidak hanya berkaitan dengan pengolahan alam dan upacara religius tetapi juga diterapkan dalam pengembangan akal atau budi manusia individu dan sikap serta perilaku lewat pembelajaran. Dalam pengertian yang lebih luas, budaya dapat mengacu ke pengembangan intelektual, spiritual, dan estetis dari seorang individu atau sebuah kelompok serta masyarakat. Istilah budaya juga sering digunakan dalam kegiatan intelektual dan estetis individu serta produk yang dihasilkan seperti film, benda seni, dan teater. Istilah budaya juga diidentikkan dengan istilah kesenian. Budaya dapat juga digunakan untuk menggambarkan keseluruhan cara hidup, berkegiatan, keyakinan, dan adat kebiasaan sejumlah orang, kelompok atau masyarakat (Sutrisno \& Putranto, 2005:8; Williams, 1981:11).

Seni, ilmu pengetahuan dan teknologi merupakan bagian dari unsur-unsur kebudayaan universal (Kluckhohn dalam Abdulsyani, 2007:46) di mana semua bangsa memilikinya meski dengan bentuk berbeda. Unsur-unsur yang lain meliputi peralatan dan perlengkapan hidup, mata pencaharian dan sistem ekonomi, sistem kemasyarakatan, bahasa, dan religi atau sistem kepercayaan. Dalam seni kekinian yang lazim disebut seni kontemporer maka kemajuan teknologi, informasi, digital, dan analog yaitu teknologi canggih dengan basis sistem radio dan pengubahan bentuk informasi dalam menyimpan informasi mengenai realita, sering disebut media baru (new media art) (Himawan, 2014:86). Sebagai bagian dari potret diri dalam medium digital, selfie tidak dapat dipisahkan dari seni, ilmu pengetahuan, dan teknologi sehingga dapat dikatakan jika selfie merupakan media baru.

Kehadiran selfie dan potret diri seolah sudah membudaya yaitu menjadi bagian dari perlengkapan hidup, sistem ekonomi, hingga sistem kemasyarakatan. Selfie hadir di mana-mana dan dalam kondisi apa pun. Di media sosial, orangorang berlomba mengunggah foto-foto aktivitas diri ataupun hal-hal di sekitarnya. Foto menjadi bagian yang tidak terpisahkan dalam kehidupan sehari-hari. Hidup tanpa foto menjadikan hidup serasa kurang lengkap. Foto bukan lagi sekadar untuk mendokumentasikan moment penting namun hampir seperti jurnal harian di mana 
hampir setiap aktivitas dicatat secara visual. Dalam sistem kemasyarakatan di mana saat interaksi tidak lagi dapat dilakukan setiap saat maka masingmasing orang memasang foto diri di dinding media sosialnya agar orang lain mengenal dirinya.

Selfie selain dilihat dari perkembangan sisi seni maka selfie juga mengalami perkembangan dari sisi isi atau imaji yang disampaikan. Masyarakat mulai beranjak pada hal-hal di luar dirinya dengan tetap memvisualkan apa-apa yang ada di sekitarnya. Sebagai contoh yaitu sebelum makan maka makanan dipotret dan diunggah ke media sosial. Perilaku yang banyak dilakukan oleh masyarakat perkotaan ini turut menyemarakkan food photography dan pernik-perniknya. Bisnis makanan ikut menjamur disertai "perang" foto untuk menarik konsumen. Tempat-tempat indah yang sebelumnya tidak begitu dikenal menjadi mudah ditemukan sehingga memunculkan tujuan wisata baru. Bisnis berbasis pariwisata menguat. Segala sesuatu menjadi harus ada gambar (foto) karena dianggap lebih menarik dan mudah dimengerti. Pada masa sekarang ini menjadi tidak mengherankan jika di lokasi strategis seperti perempatan jalan besar dipenuhi oleh banyaknya iklan berbentuk baliho billboard.

Berdasar sisi pengetahuan dan teknologi maka perangkat lunak (software) atau aplikasi fotografi semakin beragam dan mudah digunakan. Fotografi menjadi lebih mudah dipelajari. Peralatan mudah didapat. Fotografi sebelumnya termasuk dalam tingkat kebutuhan tersier yaitu sejajar dengan barang mewah. Pada tahun 90-an untuk mendapatkan kamera harus mengeluarkan uang yang banyak, mencetak foto harus ke kota besar, dan untuk mempelajari harus bertemu orang-orang yang paham betul tentang fotografi termasuk kamera dan pengoperasiannya. Pada masa sekarang ini fotografi berubah "status" menjadi kebutuhan sekunder bahkan mendekati primer. Fotografi menjadi sesuatu yang penting dan sangat dibutuhkan tetapi jika tidak terpenuhi tidak membuat manusia mati secara langsung.

Fotografi apabila masih dikatakan sebagai barang mewah menjadikan orang untuk tidak lagi ragu mengeluarkan uang lebih untuk membeli kamera ataupun berfoto atau difoto oleh fotografer profesional. Potret diri dalam foto pre-wedding misalnya maka biaya pemotretan dapat mencapai Rp 8 juta. Biaya itu bersih tanpa perlu memikirkan kostum dan perlengkapan lain. Pencarian kostum dan perlengkapan itu sendiri akan memakan biaya sekitar Rp 4 juta. Nominal akhir dalam hal ini kurang lebih sama yaitu sekitar Rp 8 juta. Hal tersebut hanya sekedar contoh dan tidak dapat dipakai sebagai ukuran untuk semua daerah apalagi semua fotografer. Nominal tersebut terdengar wajar bagi yang menikah di daerah perkotaan atau sekitarnya (Wawancara dengan Ahmad Dhamai, 2015). Dalam hal ini, budaya visual melahirkan konsumsi. Roda perekonomian turut bergerak. Keputusan dan tindakan yang dipengaruhi oleh segala sesuatu yang visual menjadikan imaji visual sebagai media yang efektif untuk menarik konsumen.

\section{Simpulan}

Fotografi dalam hal ini potret diri dan selfie menjadi bagian kehidupan masyarakat. Selfie merupakan bentuk tidak resmi (slang) dari potret diri digital (digital self-portraits) yang menjadi salah satu bagian dari kehidupan masyarakat kota. Sejak bangun tidur hingga beranjak tidur lagi maka potret diri di media sosial tidak dilupakan. Setiap aktivitas hampir mendapat porsi dalam bentuk selfie. Tanpa selfie tidak "eksis" atau ada. Eksistensi diri dengan kata lain dapat dilihat dari media sosial. Hal ini berarti bahwa apabila sering upload foto diri atau mengganti status maka berarti seseorang itu ada. Keberadaannya diakui sebagai bagian dari masyarakat di dunia maya. Di dunia realitas, keberadaan seseorang diukur atau dapat dilihat dari kiprahnya di masyarakat. Bagaimana karya-karyanya di dunia realitas? Di dunia jejaring sosial (media sosial), eksistensi masih sebatas pada sekadar ada. Seseorang itu biasanya akan sering mengunggah foto-foto dirinya atau aktivitasnya termasuk apa yang dipikirkan dan dirasakan.

National \#Selfie Gallery di London pada 2013 menunjukkan bahwa selfie memiliki keunikannya sendiri sehingga memiliki kelayakan masuk dan dipamerkan di galeri sebagai bagian dari dunia seni. Peristiwa ini membuka lembaran baru bagi dunia fotografi khususnya foto potret diri. Nilai-nilai 
seni dan estetis tersematkan dalam foto-foto selfie tersebut sejak dia lolos seleksi kurasi dan dipajang di ruang galeri. Kunjungan audiens dan respons yang didapatkan akan melengkapi keabsahan fotofoto yang disusun dalam bentuk video itu sebagai karya atau "benda seni". Nilai ekonomi tentu saja ikut naik bersamaan dengan waktu dan ruang (tempat) publikasi yang berbeda.

Potret diri yang mudah ditemui baik di dunia realitas maupun dunia maya dan media sosial akan membawa perubahan dalam kebudayaan suatu masyarakat. Segala sesuatu yang terlihat dan tertampil menjadi pathokan dalam mengambil keputusan ataupun tindakan. Di sini mulai terjadi perubahan kebudayaan yang mengarah ke pembentukan budaya visual dengan segala sesuatu selalu berkaitan atau dikaitkan dengan media visual. Sisi positifnya menjadikan masyarakat semakin berkembang. Berdasar perspektif ekonomis maka bidang visual menjadi peluang bisnis yang dapat dimasuki siapa saja. Di sisi lain terdapat peralihan cara atau model dalam berkomunikasi dan interaksi. Cara yang bersifat konvensional yaitu dengan bertemu langsung atau tatap muka dan berbincang tanpa menggunakan alat menjadi bergeser ke model digital yaitu komunikasi dan interaksi dilakukan dengan perantara alat. Suara lisan diganti dengan kata tulis di mana perasaan yang biasanya bisa langsung disampaikan dengan pelukan misalnya akan cukup diwakilkan dengan emoticon.

\section{Ucapan Terima Kasih}

Penulis mengucapkan terima kasih kepada Ketua Jurusan Fotografi, Fakultas Seni Media Rekam (FSMR), ISI Yogyakarta yang telah mengijinkan penulis menggunakan lab fotografi untuk kegiatan penelitian.

\section{Kepustakaan}

Abdulsyani. 2007. Sosiologi, Skematika, Teori, dan Terapan. Jakarta: Bumi Aksara.

Admin Web. 2015. "Iklan Axis Lucu'Ganteng Dikit Cekrek' Dijamin Ngakak". http://www. kalongkurus.com/2015/12/iklan-axis-lucuganteng-dikit-cekrek.html. (Diakses pada 14
September 2015, 01:57.

Adzani, Fadli. 2015. "Berbagai Kisah Selfie Berujung Bencana di Dunia". http://www.cnnindonesia.com/gayahidup/20150909162645-277-77676/ berbagai-kisah-selfie-berujung-bencana-didunia/. (Diakses pada 12 September 2015, $11: 17)$

Bahari, Nooryan. 2008. Kritik Seni: Wacana Apresiasi dan Kreasi. Yogyakarta: Pustaka Pelajar.

Bugin, Victor. 2010. "Makna Melihat" dalam Howard Davis \& Paul Walton (Ed.). Bahasa, Citra, Media. Yogyakarta: Jalasutra.

Garber, Megan. 2013. "And Now There Is a 'National Selfie Portrait Gallery'”. http://www. theatlantic.com/technology/archive/2013/10/ and-now-there-is-a-national-selfie-portraitgallery/280651/. (Diakses pada 12 September 2015, 19: 44).

Himawan, Willy. 2014. "Citra Budaya Melalui Kajian Historis dan Identitas: Perubahan Budaya Pariwisata Bali Melalui Karya Seni Lukis" dalam Journal of Urban Society's Arts, Vol. 1, No. 1 - April 2014.

Kusrini. 2013. "Selfie sebagai Perangkat Citra Diri Masyarakat Urban” dalam Journal of Urban Society's Arts, Vol. 13, No. 1 - April 2013.

Piliang, Yasraf Amir. 2010. Dunia yang Dilipat: Tamasya Melampaui Batas-Batas Kebudayaan. Bandung: Matahari.

Redaksi. 2015. "Selfie Masuk Kawah Merapi". http: / / www2.jawapos.com/baca/ artikel/17485/selfie-masuk-kawah-merapi. (Diakses pada 12 September 2015, 11.05).

Hardoko, Ervan (Edt.). 2015. “Ingin Buat 'Selfie' Spesial, Gadis Romania Tewas Tersengat Listrik”. http://internasional.kompas. com/read/2015/05/12/21520261/ Ingin. Buat.Selfie.Spesial.Gadis.Romania.Tewas. Tersengat.Listrik. (Diakses pada 12 September 2015, 21:16).

Moving Image. 2016. "National \#Selfie Portrait Gallery”. http://www.moving-image.info/ national-selfie-portrait-gallery/. (Diakses pada 12 September 2015, 20:45).

Oxford University Press. 2016. “selfie". http:// 
www.oxforddictionaries.com/us/ definition/ american_english/selfie. (Diakses pada 14 September 2015, 01:27).

Reznik, Eugene. 2013. "Off Your Phone and On View: The National \#Selfie Portrait Gallery”. http://time.com/3803252/off-your-phoneand-on-view-the-national-selfie-portraitgallery/. (Diakses pada 12 September 2015, 20:03).

Schirato, Tony \& Jen Webb. 2004. Reading the Visual. Australia: Allen \& Unwin.

Supartono, Alexander. 2014. "Budaya Visual, Bahasa Visual”. sejarahfoto.com/?p=825. (Diakses pada Rabu, 13 Septemberi 2015, 23:19).

Sutrisno, Mudji \& Hendar Putranto. 2005. TeoriTeori Kebudayaan. Yogyakarta: Kanisius.

The Art Story Modern Art Insight. 2015. "Marcel Duchamp, French Painter and Sculptor". http://www.theartstory.org/artist-duchampmarcel.htm. (Diakses pada 13 September
2015, 11:57).

Tim Penyusun. 2008. Kamus Besar Bahasa Indonesia. Jakarta: Pusat Bahasa Departemen Pendidikan Nasional.

Tolstoy, Leo. 1960. What is Art. New York: MacMillan.

Yohanes, David. 2015. "Selfie Lima Wisatawan Pantai Bajulmati Ini Berujung Maut, Satu Tewas, Tiga Hilang”. http://surabaya. tribunnews.com/2015/01/01/breakingnews-selfie-lima-wisatawan-pantai-bajulmatiini-berujung-maut-satu-tewas-tiga-hilang. (Diakses pada 12 September 2015, 23:19).

Williams, Raymond. 1981. Culture. Inggris: Fontana Paperbacks.

\section{Informan}

Ahmad Dhamai (30 tahun). Pengguna jasa fotografer untuk pre-wedding, tinggal di Salatiga, Jawa Tengah. 